\title{
Influence of Physico-Chemical Characteristics of Soils on Heavy Metal Contamination in Makurdi, Benue State
}

\author{
Odueze, J. Chibuzor, || Nwakonobi, T. U, || Itodo, I. N \\ Dept of Agricultural and Environmental Engineering, University of Agriculture, Makurdi. Nigeria
}

\begin{abstract}
The soil physico-chemical properties and heavy metals concentrations in different layers of the soil $(0$ - 30; 30 - 60; 60 - 90 and $90-120 \mathrm{~cm}$ depth) of Apir and Northbank automobile mechanic villages and control site at University of Agriculture, Makurdi were studied. The analysis showed the soils to be sandy loam clay, with low organic matter content (1.64 - 2.39\%)), slightly acidic $p H$ (6.29 - 6.67), high bulk density (1.49 - 1.52 $\left.\mathrm{g} / \mathrm{cm}^{3}\right)$ and porosity (42.2 - $\left.43.3 \%\right)$ across depths and locations. The soil samples were digested with a mixture of $\mathrm{HNO}$ and $\mathrm{HCl}(1: 3 \mathrm{v} / \mathrm{v})$, and analyzed for heavy metals such as $\mathrm{Cu}, \mathrm{Cr}, \mathrm{Zn}, \mathrm{Cd}, \mathrm{Mn}$, Ni and Co using Atomic Absorption Spectrophotometer. The soils showed significant levels of the metals above background concentrations with most $(\mathrm{Cu}, \mathrm{Zn}, \mathrm{Mn}, \mathrm{Cr}$ and $\mathrm{Ni})$ decreasing with soil depth. Across all the sampling locations and profiles, Mn showed the highest $(301 \mathrm{mg} / \mathrm{kg}$ ) concentration with $\mathrm{Cd}$ and Co concentrations below detectable limits ( $\leq 0)$. The distribution pattern were in the following order $\mathrm{Mn}>\mathrm{Cu}>\mathrm{Zn}>\mathrm{Cr}>\mathrm{Ni}>\mathrm{Cd}>$ Co. For some of the metals there were significant variations $(P$ 0.05) in concentration across depths and locations.
\end{abstract}

Key Words: Heavy metals, soils, mechanic workshops and Makurdi

\section{Introduction}

Soil is an essential resource to agricultural production in the world, and agricultural production is crucial to development. Human lives depend on this naturally abundant resource. It is a crucial component of rural and urban environments, and in both places land management is the key to soil quality. The contamination of soil is an important environmental problem throughout the world. The ability of contaminants to accumulate and become toxic to biological systems (plants and animals) has been reported (Balasubramanian, 2007). In most industrialized countries, the treatment and disposal of hazardous wastes is carefully controlled through a variety of regulations, policies, incentive programs and voluntary efforts.

Heavy metals in the soil originate from many sources, which include atmospheric deposition, sewage irrigation, improper stacking of the industrial solid waste like Automobile activities, mining activities, the use of pesticides and fertilizers (Zhang et al., 2011), etc. Heavy metals occur naturally in the soil environment from the pedogenetic process of weathering of parent materials at levels that are regarded as toxic.

The objectives of the study are to ddetermine the physico-chemical characteristics of soils at the two selected Mechanic villages and the control site in Makurdi, determine the presence of heavy metals such as, $\mathrm{Cd}$, $\mathrm{Cr}, \mathrm{Mn}, \mathrm{Co}, \mathrm{Cu}, \mathrm{Ni}$, and $\mathrm{Zn}$ and their levels of concentration at the selected sites and determine the level of pollution at various depths range within the soil profile. The findings from the analysis on the concentration of heavy metals at the top soil would present information on whether or not to plant in these areas as the top soils known to contain nutrients and microbes for nitrogen fixation supports agricultural activities.

The knowledge on the level of contamination of soils around surface water would aid to stop the consumption of such water and use in some agricultural activities unless it is properly treated. It can be useful in designing and managing land disposal systems and provide information for predicting heavy metal movement in soils around mechanic village and the effect around its environment.

\subsection{Study Area:}

\section{Materials And Method}

The study area is Makurdi the capital city of Benue State in Nigeria, located on latitude $07^{\circ} 41^{1} \mathrm{~N}$ and longitude $08^{\circ} 37^{1}$. It is one of Nigeria's largest cities and it has an estimated motor vehicle population of over 100,000 (Usmanet, 2013). Sizes of these sites vary but the typical size occupies less than 1 ha of land area (Table 4), containing more than 40 to 50 auto-mechanic workshops and serves about 400 to 500 vehicles daily. Activities conducted in these shops are typical of auto-mechanic repair and invariably involve working with and spilling of oils, greases, petrol, diesel, battery electrolyte, paints and other materials which contain heavy metals to bare soil and consequently infiltrate in the soil. The areas of study are the largest and oldest mechanic village sites located within Makurdi metropolis. These are located at Kanshio which is known as Apir mechanic village and the North bank area well known for repairing and maintaining automobiles with a large clientele. They are located along Makurdi-Otukpo road opposite the National Open University, Makurdi and Makurdi-Lafia road in 
Makurdi respectively. There are no mechanic activities in the University of Agriculture, Makurdi area, soils in this area can be used as a control to monitor or compare the levels of soil contamination at the hot spots (Apir and North bank mechanic villages). These sites were chosen for investigation, being the major auto mechanic workshop cluster in the Makurdi Metropolitan Area and are characterized by a moderate population of humans with its chains of motor sprayers, vulcanizes and other various forms of business activities.

\subsection{Soil Sampling}

\section{Data Collection}

A combination of judgemental sampling and randomization techniques were used in collecting samples for the study. In judgemental sampling, sample sites are selected based on prior knowledge of contaminant distribution (e.g hot spots) established from the site history, evidence of staining, and professional judgment. The number of samples was determined using the hot spot detection method. As indicated by Ministry for the Environment (2011) the hot spot detection is based on detecting circular hotspots with $95 \%$ confidence using a square grid sampling pattern. The minimum sampling points required for the site characterization in this study were computed as follows;

$$
\begin{aligned}
\mathrm{G} & =\mathrm{R} / 0.59 \\
\mathrm{~N} & =\mathrm{A} / \mathrm{G}
\end{aligned}
$$

Where;

$\mathrm{G}=$ distance between two sampling points (the grid size of the sampling pattern, in metres) $\mathrm{R}=$ radius of the smallest hot spot that the sampling intends to detect, in metres

0.59 = factor derived from $95 \%$ detection probability assuming circular hot spots $=$ number of sampling points needed

$=$ size of the sampling area, in square metres.

The selected automobile villages (hot spots) used in the investigation were located at Apir and North bank, the control spot used was at University of Agriculture, Makurdi. Each study site was divided into three (3) sub hot spot area and three (3) soil samples collected for each, making a total of nine (9). In order to have a comparative idea about the levels of contamination, samples collected at University of Agriculture, Makurdi were taken to be the unpolluted or background value. The background value of an element is the maximum level of the element in an environment beyond which the environment is said to be polluted by the element.

Soil samples were homogenised in triplicates at each site at depths of 0 to 30; 30 to 60; 60 to 90; and 90 to $120 \mathrm{~cm}$ using a depth calibrated soil auger for collection. Each sample was immediately placed in a fresh polygene bag and tightly sealed. All the samples were transported to the laboratory where on arrival, analytical procedure commenced immediately.

\subsection{Laboratory Analysis}

The laboratory analysis for physico-chemical properties of soils were carried out at the Soil Science Laboratory, University of Agriculture, Makurdi and the heavy metal analysis were done at the Advanced Chemistry Laboratory, Sheda Science and Technology, Abuja, Nigeria. Physico-chemical properties of soils in the selected sites such soil $\mathrm{pH}$, particle size distributions, bulk density, porosity, and organic matter content were tested using standard laboratory procedures. The soil $\mathrm{pH}$ values were measured using a $\mathrm{pH}$ meter. Particle size analysis involves the determination of the percentage of different grain sizes contained within a soil (i.e., the percentage of sand, silt and clay fractions) of the soil mass. The particle size distribution was determined by the hydrometer method using Sodium hexametaphosphate as the dispersant (Bouyoucous, 1962). Bulk density is the weight per unit volume of a soil sample $\left(\mathrm{kg} / \mathrm{m}^{3}\right)$. Bulk density was determined using the core sample method. The porosity of a soil is expressed as a percentage of the total volume of the soil material. The method used was from calculated bulk density by the equation;

\section{Bulk}

Density

Porosity $(\%)=\left(1-\frac{\text { Density }}{2.65}\right) 100 \quad \%$

Organic matter is important in the soil to improve soil structure, nutrient-holding capacity, water holding capacity and infiltration. The Walkley-Black Method (Walkley and Black, 1934) was used. The soil samples were spread on clean plastic sheets and air dried in an open air in the laboratory under room temperature of within $23-27{ }^{\circ} \mathrm{C}$ for 24 hours. Afterwards, the soils were sieved on a $2 \mathrm{~mm}$ sieve and $2 \mathrm{~g}$ samples 
taken from the sieved soil and placed in a $100 \mathrm{ml}$ beaker. $10 \mathrm{~cm}^{3}$ of aqua regia (ratio 3:1 HCL: HNO3) was added to each of the samples. The samples were heated on the hot plate at $70{ }^{\circ} \mathrm{C}$. The digest then cooled and diluted with deionised water. It was filtered into a $50 \mathrm{ml}$ volumetric flask and made up to mark, and stored in a polypropylene bottle. Blank samples were carried through the same process and stored in polypropylene bottles and allowed to cool to room temperature. The analytes were analysed for the different metals using an Atomic Absorption Spectrophotometer (AAS model iCE 3000 AA02134104v1.30) and the resulting data presented in Tables.

\subsection{Analysis of Results}

Simple descriptive statistical techniques such as tabulation, computation of totals, averages and standard deviations were utilized for preliminary handling of data. Bar charts were used to visualize the effects of the physico-chemical characteristics and heavy metal content of soil across depth and sites. The soil data obtained from the field sampling were all subjected to analysis of variance (ANOVA) followed by least significance difference test (LSD) so as to separate the significant means. GenStat statistical package was utilized in analysing the significance of variations within and between samples this involved using ANOVA Ftest to evaluate differences between means (location and depth).

\subsection{Physico-chemical Characteristics of the Soils}

\section{Results}

The physicochemical characteristics of soil analysed for this study include particle size distribution, $\mathrm{pH}$ level, bulk density, percentage porosity and organic matter content across the various depths for the control site (UAM), Apir and Northbank automobile mechanic villages. Mean values and standard deviations (S.D) of these soil characteristics investigated are summarized in Table 1 . The properties of the soils are shown at four depths for the selected sampling areas in Makurdi $(0-30,30-60,60-90$ and $90-120 \mathrm{~cm})$.

Analysis of Variance (ANOVA) within the sample means across sampling depths, location and combine effects of depth and location for the physico-chemical properties of the soils revealed some significant differences, hence Fishers' least significance difference test (F-LSD) was used to make pairwise comparisons of the means as presented in Table 2 .

\subsection{Heavy Metal Accumulation in Soils}

Mean values and standard deviations (S.D) of the heavy metals concentrations at the various sites and soil profiles (depths) are presented in Table 3. Each site show variations in concentrations of Cadnium $(\mathrm{Cd})$, Copper $(\mathrm{Cu})$, Manganese $(\mathrm{Mn})$, Chromium (Cr),Nickel $(\mathrm{Ni})$, Zinc $(\mathrm{Zn})$ and Cobalt $(\mathrm{Co})$. To evaluate the significance of the heavy metal contaminations ANOVA $(\mathrm{P}<0.05)$ was conducted involving the variations in contamination across the soil depths $(0-30,30-60,60-90$ and $90-120 \mathrm{~cm})$ at which samples were collected and variations across the various sites (Apir, Northbank and UAM) and the combine effect of sampling depths and sites. The F-LSD test showing the mean concentration of heavy metals in the various soils with respect to location and depth of soils is presented in Table 4.

Table 1: Physico-chemical Properties of Soils at the selected sites in Makurdi

\begin{tabular}{|l|l|l|l|l|l|l|l|}
\hline Parameters & Samples & $0-30 \mathrm{~cm}$ & $30-60 \mathrm{~cm}$ & $60-90 \mathrm{~cm}$ & $90-120 \mathrm{~cm}$ & Mean & S.D \\
\hline \%Sand & & & & & & & \\
\hline & Apir & 75.73 & 73.31 & 74.64 & 71.31 & 73.75 & 4.433 \\
\hline & NorthBank & 77.97 & 75.97 & 72.83 & 71.49 & 74.567 & 18.911 \\
\hline & Control & 77.40 & 77.73 & 74.64 & 72.83 & 75.650 & 3.199 \\
\hline & & & & & & & \\
\hline & Apir & 15.69 & 20.69 & 16.69 & 19.03 & 18.027 & 3.434 \\
\hline & NorthBank & 15.60 & 16.17 & 17.69 & 19.03 & 17.122 & 4.243 \\
\hline & Control & 14.03 & 14.50 & 18.39 & 16.17 & 15.773 & 2.640 \\
\hline & & & & & & & \\
\hline & Apir & 8.57 & 6.00 & 8.67 & 9.67 & 8.227 & 2.186 \\
\hline & NorthBank & 6.43 & 7.85 & 9.48 & 9.48 & 8.31 & 2.486 \\
\hline & Control & 8.57 & 7.77 & 6.97 & 11.00 & 8.577 & 2.537 \\
\hline pH & & & & & & \\
\hline & Apir & 6.600 & 6.493 & 6.440 & 6.487 & 6.505 & 0.139 \\
\hline & NorthBank & 6.833 & 6.667 & 6.627 & 6.573 & 6.675 & 1.747 \\
\hline & Control & 6.210 & 6.260 & 6.313 & 6.367 & 6.288 & 0.065 \\
\hline Bulk Density & & & & & & & \\
\hline & Apir & 1.460 & 1.550 & 1.500 & 1.497 & 1.502 & 0.102 \\
\hline & NorthBank & 1.397 & 1.507 & 1.590 & 1.573 & 1.517 & 0.389 \\
\hline & Control & 1.573 & 1.450 & 1.497 & 1.433 & 1.488 & 0.105 \\
\hline & & & & & & \\
\hline
\end{tabular}


Influence of Physico-Chemical Characteristics of Soils on Heavy Metal Contamination in Makurdi,

\begin{tabular}{|l|l|l|l|l|l|l|l|} 
& Apir & 44.34 & 40.91 & 42.81 & 42.94 & 42.750 & 3.869 \\
\hline & NorthBank & 46.75 & 42.56 & 39.38 & 40.02 & 42.178 & 10.817 \\
\hline & Control & 40.02 & 44.72 & 42.94 & 45.63 & 43.258 & 4.005 \\
\hline Organic matter & & & & & & & \\
\hline & Apir & 1.977 & 1.373 & 1.780 & 1.630 & 1.690 & 0.559 \\
\hline & NorthBank & 1.283 & 1.800 & 1.797 & 1.687 & 1.642 & 0.384 \\
\hline & Control & 3.417 & 2.367 & 1.923 & 1.803 & 2.378 & 0.786 \\
\hline
\end{tabular}

Table 2: Physico-chemical Characteristics of Soil with respect to Location and Depth of Soil

\begin{tabular}{|l|l|l|l|l|l|l|l|l|}
\hline Location & Depth & pH & Bulk Density & Organic Matter & \% Sand & \% Clay & \% Silt & \% Porosity \\
\hline Apir & $0-30$ & $6.600^{\text {def }}$ & $1.460^{\mathrm{NS}}$ & $1.977^{\mathrm{a}}$ & $75.73^{\mathrm{NS}}$ & $15.69^{\mathrm{ab}}$ & $8.57^{\mathrm{ab}}$ & $44.34^{\mathrm{NS}}$ \\
\hline \hline & $30-60$ & $6.493^{\text {cdef }}$ & $1.550^{\mathrm{NS}}$ & $1.373^{\mathrm{ab}}$ & $73.31^{\mathrm{NS}}$ & $20.69^{\mathrm{b}}$ & $6.00^{\mathrm{a}}$ & $40.91^{\mathrm{NS}}$ \\
\hline & $60-90$ & $6.440^{\mathrm{bcd}}$ & $1.500^{\mathrm{NS}}$ & $1.780^{\mathrm{ab}}$ & $74.64^{\mathrm{NS}}$ & $16.69^{\mathrm{ab}}$ & $8.67^{\mathrm{ab}}$ & $42.81^{\mathrm{NS}}$ \\
\hline & $90-120$ & $6.487^{\mathrm{cde}}$ & $1.497^{\mathrm{NS}}$ & $1.630^{\mathrm{ab}}$ & $71.31^{\mathrm{NS}}$ & $19.03^{\mathrm{ab}}$ & $9.67^{\mathrm{ab}}$ & $42.94^{\mathrm{NS}}$ \\
\hline North. B & $0-30$ & $6.833^{\mathrm{g}}$ & $1.397^{\mathrm{NS}}$ & $1.283^{\mathrm{a}}$ & $77.97^{\mathrm{NS}}$ & $15.60^{\mathrm{ab}}$ & $6.43^{\mathrm{a}}$ & $46.75^{\mathrm{NS}}$ \\
\hline & $30-60$ & $6.667^{\mathrm{f}}$ & $1.507^{\mathrm{NS}}$ & $1.800^{\mathrm{ab}}$ & $75.97^{\mathrm{NS}}$ & $16.17^{\mathrm{ab}}$ & $7.85^{\mathrm{ab}}$ & $42.56^{\mathrm{NS}}$ \\
\hline & $60-90$ & $6.627^{\mathrm{ef}}$ & $1.590^{\mathrm{NS}}$ & $1.797^{\mathrm{ab}}$ & $72.83^{\mathrm{NS}}$ & $17.69^{\mathrm{ab}}$ & $9.48^{\mathrm{ab}}$ & $39.38^{\mathrm{NS}}$ \\
\hline UAM & $90-120$ & $6.573^{\mathrm{def}}$ & $1.573^{\mathrm{NS}}$ & $1.687^{\mathrm{ab}}$ & $71.49^{\mathrm{NS}}$ & $19.03^{\mathrm{ab}}$ & $9.48^{\mathrm{ab}}$ & $40.02^{\mathrm{NS}}$ \\
\hline & $0-30$ & $6.210^{\mathrm{a}}$ & $1.573^{\mathrm{NS}}$ & $3.417^{\mathrm{c}}$ & $77.40^{\mathrm{NS}}$ & $14.03^{\mathrm{a}}$ & $8.57^{\mathrm{ab}}$ & $40.02^{\mathrm{NS}}$ \\
\hline & $30-60$ & $6.260^{\mathrm{a}}$ & $1.450^{\mathrm{NS}}$ & $2.367^{\mathrm{b}}$ & $77.73^{\mathrm{NS}}$ & $14.50^{\mathrm{a}}$ & $7.77^{\mathrm{ab}}$ & $44.72^{\mathrm{NS}}$ \\
\hline & $60-90$ & $6.313^{\mathrm{ab}}$ & $1.497^{\mathrm{NS}}$ & $1.923^{\mathrm{ab}}$ & $74.64^{\mathrm{NS}}$ & $18.39^{\mathrm{ab}}$ & $6.97^{\mathrm{ab}}$ & $42.94^{\mathrm{NS}}$ \\
\hline LSD(0.05) & $90-120$ & $6.367^{\mathrm{abc}}$ & $1.433^{\mathrm{NS}}$ & $1.803^{\mathrm{ab}}$ & $72.83^{\mathrm{NS}}$ & $16.17^{\mathrm{ab}}$ & $11.00^{\mathrm{b}}$ & $45.36^{\mathrm{NS}}$ \\
\hline
\end{tabular}

Means with the same letters are not significantly different from each other NS= Not significant.

Table 3: Summary of Heavy Metals pollution at various depths of the soil of auto mobile sites compared to the non-automobile site.

\begin{tabular}{|c|c|c|c|c|c|c|c|}
\hline Metal & \begin{tabular}{|l|} 
Location \\
\end{tabular} & $0-30 \mathrm{~cm}$ & $30-60 \mathrm{~cm}$ & $60-90 \mathrm{~cm}$ & $90-120 \mathrm{~cm}$ & Mean & S.D \\
\hline \multicolumn{8}{|c|}{ Cadmium } \\
\hline & Apir & 0.066 & * & $*$ & 0.116 & 0.046 & 0.048 \\
\hline & NorthBank & $*$ & 0.118 & $*$ & $*$ & 0.030 & 0.051 \\
\hline & Control & $*$ & * & $*$ & $*$ & * & * \\
\hline \multicolumn{8}{|c|}{ Copper } \\
\hline & Apir & 33.499 & 8.366 & 8.366 & 7.687 & 14.479 & 10.985 \\
\hline & NorthBank & 314.818 & 54.202 & 13.599 & 7.073 & 97.423 & 126.805 \\
\hline & Control & 10.722 & 10.252 & 13.668 & 20.467 & 13.777 & 4.078 \\
\hline \multicolumn{8}{|c|}{ Manganese } \\
\hline & Apir & 96.291 & 250.510 & 105.551 & 180.963 & 158.079 & 88.895 \\
\hline & NorthBank & 174.15 & 300.943 & 284.100 & 210.028 & 242.305 & 108.943 \\
\hline & Control & 161.140 & 78.0708 & 51.384 & 37.105 & 82.844 & 25.004 \\
\hline \multicolumn{8}{|c|}{ Chromium } \\
\hline & Apir & 11.291 & 16.513 & 17.812 & 30.660 & 19.069 & 7.123 \\
\hline & NorthBank & 26.150 & 11.548 & 13.098 & 12.614 & 15.853 & 5.972 \\
\hline & Control & 8.814 & 9.385 & 13.838 & 7.773 & 9.953 & 2.317 \\
\hline \multicolumn{8}{|l|}{ Nickel } \\
\hline & Apir & 2.573 & 3.329 & 6.130 & 17.031 & 7.266 & 5.791 \\
\hline & NorthBank & 1.097 & 2.049 & 1.778 & 3.427 & 2.087 & 0.847 \\
\hline & Control & 2.095 & 0.785 & $*$ & $*$ & 0.720 & 0.856 \\
\hline \multicolumn{8}{|l|}{$\overline{\text { Zinc }}$} \\
\hline & Apir & 35.469 & 6.158 & 3.563 & 4.570 & 12.440 & 13.328 \\
\hline & NorthBank & 120.237 & 67.626 & 25.733 & 5.127 & 54.681 & 44.042 \\
\hline & Control & 5.623 & 5.639 & 7.830 & 15.956 & 8.762 & 4.249 \\
\hline & & & & & & & \\
\hline \multicolumn{8}{|l|}{ Cobalt } \\
\hline & Apir & 0.215 & 0.673 & * & * & 0.222 & 0.275 \\
\hline & NorthBank & $*$ & * & 0.016 & $*$ & 0.004 & 0.007 \\
\hline & Control & $*$ & * & $*$ & $*$ & $*$ & * \\
\hline
\end{tabular}

(*) Represents heavy metal concentrations not detectable. -

Heavy metal concentrations are in $\mathrm{kg} / \mathrm{mg}$.

Table 4: Effect of Heavy Metals on Soils with respect to Location and Depth of Soils.

\begin{tabular}{|l|l|l|l|l|l|l|l|l|}
\hline & Depth & Cd & Cu & Mn & Cr & Ni & Zn & Co \\
\hline Apir & $0-30$ & $0.065^{\mathrm{b}}$ & $33.0^{\mathrm{a}}$ & $96.0^{\mathrm{ab}}$ & $11.3^{\mathrm{ab}}$ & $2.6^{\mathrm{NS}}$ & $35.5^{\mathrm{ab}}$ & $0.22^{\mathrm{b}}$ \\
\hline & $30-60$ & $*$ & $8.0^{\mathrm{a}}$ & $251.0^{\mathrm{ab}}$ & $16.5^{\mathrm{ab}}$ & $3.3^{\mathrm{NS}}$ & $6.2^{\mathrm{a}}$ & $0.67^{\mathrm{b}}$ \\
\hline & $60-90$ & $*$ & $8.0^{\mathrm{a}}$ & $106.0^{\mathrm{ab}}$ & $17.8^{\mathrm{ab}}$ & $6.1^{\mathrm{NS}}$ & $3.5^{\mathrm{a}}$ & $*$ \\
\hline
\end{tabular}




\begin{tabular}{|l|l|l|l|l|l|l|l|l|} 
& $90-120$ & $0.118^{\mathrm{b}}$ & $8.0^{\mathrm{a}}$ & $181.0^{\mathrm{ab}}$ & $30.7^{\mathrm{b}}$ & $17^{\mathrm{NS}}$ & $4.2^{\mathrm{a}}$ & $*$ \\
\hline $\begin{array}{l}\text { North } \\
\text { bank }\end{array}$ & $0-30$ & $*$ & $315.0^{\mathrm{b}}$ & $174.0^{\mathrm{ab}}$ & $26.1^{\mathrm{ab}}$ & $1.1^{\mathrm{NS}}$ & $120.2^{\mathrm{b}}$ & $*$ \\
\hline & $30-60$ & $*$ & $54.0^{\mathrm{a}}$ & $301.0^{\mathrm{b}}$ & $11.5^{\mathrm{ab}}$ & $2.0^{\mathrm{NS}}$ & $67.6^{\mathrm{ab}}$ & $*$ \\
\hline & $60-90$ & $*$ & $14.0^{\mathrm{a}}$ & $284.0^{\mathrm{b}}$ & $13.1^{\mathrm{ab}}$ & $1.8^{\mathrm{NS}}$ & $24.9^{\mathrm{ab}}$ & $*$ \\
\hline & $90-120$ & $*$ & $7.0^{\mathrm{a}}$ & $210.0^{\mathrm{ab}}$ & $12.6^{\mathrm{ab}}$ & $3.4^{\mathrm{NS}}$ & $4.4^{\mathrm{ab}}$ & $*$ \\
\hline Control & $0-30$ & $*$ & $11.0^{\mathrm{a}}$ & $161.0^{\mathrm{ab}}$ & $8.8^{\mathrm{a}}$ & $2.1^{\mathrm{NS}}$ & $5.6^{\mathrm{a}}$ & $*$ \\
\hline & $30-60$ & $*$ & $10.0^{\mathrm{a}}$ & $78.0^{\mathrm{ab}}$ & $9.4^{\mathrm{a}}$ & $0.8^{\mathrm{NS}}$ & $5.6^{\mathrm{a}}$ & $*$ \\
\hline & $60-90$ & $*$ & $14.0^{\mathrm{a}}$ & $51.0^{\mathrm{a}}$ & $13.8^{\mathrm{ab}}$ & $*$ & $7.8^{\mathrm{a}}$ & $*$ \\
\hline & $90-120$ & $*$ & $20.0^{\mathrm{a}}$ & $37.0^{\mathrm{a}}$ & $7.8^{\mathrm{a}}$ & $*$ & $16.0^{\mathrm{ab}}$ & $*$ \\
\hline
\end{tabular}

-Means with the same letters along same column are not significantly different from each other. -NS= Not significant.

\subsection{Physico-chemical Characteristics of the Soils}

\section{Discussion}

Physico-chemical characteristics of soil such as particle size distribution, $\mathrm{pH}$, bulk density, porosity and organic matter are known to influence the interactions and dynamics of metals within the soil matrix. Table 1 shows varying composition of these physico-chemical characteristics in the samples and the statistical levels of significance across depths and locations which have important implication for heavy metal accumulations at the study sites.

\section{Particle size distribution}

The particle size distribution as presented in Table 1 put the soils in the sandy clay loam textural class. Sandy clay loam soils have low sorption capacity for metal ions due to their sandy texture. No significant difference was observed for percentage clay across the various depths of the three sites except for depth of 30$60 \mathrm{~cm}$ (Apir soil) and depth 0-30/30-60 cm (UAM) which are significantly different from each other. For silt, depth of 30-60 cm of Apir soil was significantly different from depth 90-120 cm of UAM soil, likewise depth of 0-30 cm of Northbank soil and depth of 90-120 cm of UAM soil. No significant differences were observed between depth 0-30, 30-60 and 60-90 for percentage sand and percentage silt, however, significant difference was observed between depth $90-120$ and 0-30/30-60 cm respectively for the two parameters. The particle size analysis (Table 2$)$ of the soils with respect to location revealed insignificant differences $(\mathrm{P}<0.05)$ across the three sites for percentage sand, clay and silt compositions. As a result of these variations in the particle distribution it is expected that the concentrations of elements of interest, $\mathrm{Cu}, \mathrm{Zn}, \mathrm{Mn}, \mathrm{Ni}$, Co and $\mathrm{Cd}$ may increase with depth, possibly due to leaching from the surface (Myung, 2008).

\section{Soil pH}

The mean values of the $\mathrm{pH}$ of soils in the vicinity of the control site, Apir and North Bank auto mechanic villages were $6.505 \pm 0.139,6.675 \pm 1.747$ and $6.228 \pm 0.065$ (Table 1) in deionized water, respectively, which suggests that the soils are moderately acidic, in situ. These values are in line with Banjoko and Sobulo (1994), that some Nigerian soils are within a $\mathrm{pH}$ range of $5.70-6.50$ and this is taken as the normal $\mathrm{pH}$ range for ordinary soils that favour plant growth and viability of micro-organisms.

Significant difference $(\mathrm{P}<0.05)$ was observed for $\mathrm{pH}$ level of the soils across the three sites. No significant difference $(\mathrm{P}<0.05)$ was observed in Northbank between the depth of 30-60 cm, 60-90 cm and 90$120 \mathrm{~cm}$, however, significant difference was observed between the three depths and depth of $0.30 \mathrm{~cm}$ in Northbank. No significant differences were observed across the four depths in UAM soils for pH level (Table 2) this is also depicted in Figure 6. Therefore the movement of these cations from the surface to the underlying soil layer will be at a slow rate. Significant difference $(\mathrm{P}<0.05)$ was observed across the three sites for $\mathrm{pH}$. The variability of the $\mathrm{pH}$ values obtained for the soils may suggest an indication that $\mathrm{pH}$ effect on the availability of the metals is significant. It is a fact that $\mathrm{pH}$ is an important soil property, having great effects on solute concentration and sorption/desorption of contaminant in soil. High $\mathrm{pH}$ might reduce the mobility of some metal species down the soil strata while low $\mathrm{pH}$ values usually enhance metal distribution and transport in soil.

\section{Bulk density}

The bulk density of the soils at the three different sites presented in Table 6 showed that for Apir the mean bulk density was $1.502 \pm 0.102 \mathrm{~g} / \mathrm{cm}^{3}, 1.517 \pm 0.389 \mathrm{~g} / \mathrm{cm}^{3}$ for Northbank and $1.488 \pm 0.104 \mathrm{~g} / \mathrm{cm}^{3}$ for the control site. According to Brady (1990) a variation from 1.20 to $1.80 \mathrm{~g} / \mathrm{cm}^{3}$ may be found in sands and sandy loams, however, organic matter contents are generally low, the solid particles lie quite closely together, and the bulk densities are commonly higher than in the fine-textured soils. Values of bulk density presented in Tables 2 revealed no significant differences across the various depths of the three sites.

Porosity 
The soil porosity for Apir was $42.75 \pm 3.869 \%, 42.178 \pm 10.817$ for Northbank and $43.258 \pm 4.005 \%$ for the control site (Table 1). The entire study area ranged from $39.38 \%$ to $46.75 \%$. The range shows a moderate to high porosity across the different sites, this is an indication that the soil is less dense and contains high volume of voids relative to the volume of solids. The porosity of these soils encourages infiltration and percolation rather than surface runoff. The percentage porosity showed no significant differences across the various depths and three sites (Tables 2).

\section{Organic matter}

The amount of organic matter in the soils for Apir was $1.69 \pm 0.559 \%, 1.642 \pm 0.348 \%$ for Northbank and $2.378 \pm 0.786 \%$ for the control site (Table 1). The organic matter for the study area was in the range of 1.373 to $3.417 \%$. Similar amount of organic matter has been reported by Akoto et al. (2008) to have the potential to bind toxic ions. It plays an important role in metal binding (Akan et al., 2010). Organic matter of soils immobilizes heavy metals at strongly acidic conditions and mobilizes metals at weakly acidic to alkaline reactions by forming insoluble or soluble organic metal complexes, respectively (Brümmer and Herms, 1982).

No Significant differences were observed across the depths (Table 2) of 30-60, 60-90 and 90-120 cm for percentage organic matter but the soil properties for depth of 0-30 cm differs significantly $(\mathrm{P}<0.05)$ from depth 90-120 cm. No significant difference was observed between Apir and Northbank but both sites were significantly different from UAM (control) for organic matter (Table 2). No significant differences were observed across the depths of the three sites (Table2) except for depth 0-30 cm at Northbank soil, depth 0-30 cm at UAM and depth $30-60 \mathrm{~cm}$ at UAM soil which are significantly different from one another for organic matter.

\subsection{Heavy Metals Accumulation in the Soils with respect to Depth and Location}

The mean concentration of heavy metals analyzed for the control (UAM) site, Apir and North bank auto-mechanic villages were indicated in Table 3. Results obtained revealed higher concentration of heavy metal from auto-mechanic villages as compared to the control site soil samples, but lower than the results obtained by Luter et al. (2001) and Pam et al. (2013) that carried out similar investigations in Makurdi. This could be attributed to the availability of significant heavy metal concentration in the wastes disposals at these sites which are eventually leached into the underlying soils. In terms of concentrations of the metals in the soil layers, Mn generally has the highest while Co generally has the least and the order observed for this study is $\mathrm{Mn}>\mathrm{Cu}>\mathrm{Zn}$ $>\mathrm{Cr}>\mathrm{Ni}>\mathrm{Cd}>\mathrm{Co}$ (Table 3). Furthermore as observed from the results regarding depth through the soil layers, the highest concentrations of the metals were recorded in the 30 to $60 \mathrm{~cm}$ layer while the least were recorded in the 90 to $120 \mathrm{~cm}$ of the soil in most cases except $\mathrm{Mn}$ and $\mathrm{Ni}$ (which may be associated with its chemical form of existence in that soil environment) and this shows a linear correlation of reduction with depth through the soil layers. Most of the elements have a wide range of variations of several magnitudes. This observation of higher concentration of the metals in the top layers of the soils suggests accumulation in surface horizons of the soils and therefore, the metals may be prone to migration or intrusion into the immediate localities in the vicinity.

\section{Cadmium $(\mathrm{Cd})$ concentration in the soil}

The concentrations of Cadmium (Table 3) in the soils collected from the auto-mobile villages were below $0.1 \mathrm{mg} / \mathrm{kg}$ indicting trace concentrations while for the control site it was below detectable limits (shown with a negative sign) these were $0.045 \pm 0.048 \mathrm{mg} / \mathrm{kg}$ at Apir, $0.02958 \pm 0.0151 \mathrm{mg} / \mathrm{kg}$ at Northbank and $0.386 \pm 0.084 \mathrm{mg} / \mathrm{kg}$ at the control site. Table 4 presents the mean accumulation of heavy metals on soils with respect to location and depth of soils. No significant differences were observed across all the depths of the three sites except for UAM (depth 90-120 cm) which was significantly different from Northbank (30-60), Apir (90$120 \mathrm{~cm})$ and Apir $(0-30 \mathrm{~cm})$. Cadmium is a modern metal that is used in the auto-mobiles instead of zinc to galvanise iron and steel (Alloway, 1990 and Tucker et al., 2003).The allowable limit of Cd set by United kingdom and Luxemburg is at $3 \mathrm{mg} / \mathrm{kg}$. $1 \mathrm{mg} / \mathrm{kg}$ of $\mathrm{Cd}$ for Agricultural soils is set by Norway (Reman et.al., 1997), Germany, Ireland, Spain, Portugal and Switzerland set the value at $0.8 \mathrm{mg} / \mathrm{kg}$ (ECDGE, 2010) while Sweden set the value at $0.4 \mathrm{mg} / \mathrm{kg}$ (ECDGE, 2010). The findings showing Cd to be below detectable limit, suggest that $\mathrm{Cd}$ is not present in the soil and since it is a modern metal at use, it may be that its usage is not in large quantity or it has not stayed long enough in the soil to be detectable because Cadmium are deposited in the soil when the iron metals are weak, and some heavy metals may stay very long before their dictation. This is similar to the findings in a study by Oguntimehin and Ipinmoroti (2008) in Akure that show the maximum level of $\mathrm{Cd}$ in the soil as established by other regulatory bodies or agencies were not at these auto-mobile mechanic sites and its environ explaining that it has no effect at the moment.

\section{Copper $(\mathrm{Cu})$ concentration in the soil}


Mean Copper $(\mathrm{Cu})$ concentration in the soil at the sampling sites presented in Tables 3 revealed that the concentrations at Apir and the Control sites were similar, however $\mathrm{Cu}$ concentration in the North bank location were considerably higher than the other sampling sites. This may be attributed to the differences in naturally occurring $\mathrm{Cu}$ concentrations, the disposal habits and the volume of $\mathrm{Cu}$ content wastes in the sites. The $\mathrm{Cu}$ content that were observed in the three sites shows that the $\mathrm{Cu}$ content in the soil decreases as it moves downward the profile except that at the control site which proves otherwise. This decrease of $\mathrm{Cu}$ concentration in the soil agrees with the findings of Alloway (1990) and Lenntech (2009) who said that when $\mathrm{Cu}$ ends up in soils, it strongly attaches it's self to the organic matter and mineral as a result it does not travel very far after release. Perhaps this explains the highest values of $\mathrm{Cu}$ recorded at the two auto mechanic village sites were located at the top depth of $0-30 \mathrm{~cm}$. No significant difference was noticed across all the depths of the three sites, except for Northbank location at depth $0-30 \mathrm{~cm}(315 \mathrm{mg} / \mathrm{kg})$ which was significantly different from the others (Table 4). Elevated levels of $\mathrm{Cu}$ at these auto-mechanic sites are traceable to the high use of copper conductors and wires, tubes, solders and myriads of other maintenance items made from copper. The allowable and toxic limit of copper for agricultural soils is $250 \mathrm{mgkg}^{-1}$ as set by USEPA (1996).Table 10 and 5 shows the concentration of $\mathrm{Cu}$ in the soil at North bank auto-mechanic on depth $0-30 \mathrm{~cm}$ as $315 \mathrm{mg} / \mathrm{kg}$, which is higher than the allowable and toxic limit while that of Apir is at $33 \mathrm{mg} / \mathrm{kg}$ then the control is at $20 \mathrm{mg} / \mathrm{kg}$ which are within the allowable limits. This indicates that north bank auto mechanic soil is high in $\mathrm{Cu}$ concentration. On $\mathrm{Cu}$ rich soils only limited number of plants have the chances of survival and also shows that the soil is prone to leaching as confirmed by Lenntech (2009) who said that leaching occur in the soil when the copper level in the soil exceeds its capacity.

\section{Manganese (Mn) concentration in the soil}

From Table 3 it was observed that the highest concentration of Manganese (Mn) was $301 \mathrm{mg} / \mathrm{kg}$ at the depth of 30-60 cm in North bank. The highest concentration that was obtained at the Control site was $78 \mathrm{mg} / \mathrm{kg}$ which was obtained at the depth of $30-60 \mathrm{~cm}$ while At Apir auto mechanic site the highest concentration was at $251 \mathrm{mg} / \mathrm{kg}$ at the depth $30-60 \mathrm{~cm}$. No significant differences were noticed across the depths of the three sites except for UAM (0-30 and 90-120 cm) which though were not significantly different from each other, but were significantly different from that of Apir and Northbank (60-90 and 90-120 cm). As shown in Table 4 no significant difference was observed between Apir and Northbank for Mn concentration, like wise Apir and UAM. But significant differences were observed between Northbank and UAM.

The European commission (EC) limit and maximium tolerable level proposed for agricultural soil is $1500 \mathrm{mg} / \mathrm{kg}$ (ECDGE, 2010). According to Lindsay and Norvell (1979), soil generally contains 200-300 mg/kg of Manganese with an average of $600 \mathrm{mg} / \mathrm{kg}$. The concentration of manganese obtained in the study is high as compared to results of other studies in Nigeria such as Luter et al. (2011), Pam et al. (2013) and Olodade et al., (2015). From the observed results it can be asserted that the Mn concentrations at the sample areas are lower than the maximum tolerable level for agricultural soils. The findings show that manganese has no treat risk at the various sites under observation.

\section{Chromium $(\mathrm{Cr})$ concentration in the soil}

The accumulated Chromium (Cr) concentration at the Apir $(19.069 \pm 7.123 \mathrm{mg} / \mathrm{kg})$ and North bank $(15.850 \pm 5.972 \mathrm{mg} / \mathrm{kg})$ automobile villages were indicated in Table 3. From Table 4, no significant differences were observed for $\mathrm{Cr}$ concentrations across the various depths of the three sites, except UAM $(90-120 \mathrm{~cm})$ which was significantly different from Apir $(0-30,30-60$ and 90-120 cm) and Northbank $(0-30 \mathrm{~cm})$ but not significantly different from the rest. The results revealed that there is no significant difference in Apir and Northbank for $\mathrm{Cr}$ concentration, likewise in Northbank and UAM (control), however, significant difference was observed between Apir and UAM. UAM (control) site has the lowest concentration with $10.0 \mathrm{mg} / \mathrm{kg}$. The combined effect of location and depth as presented in Table 4 showed that at depth $90-120 \mathrm{~cm}$ Apir site has the highest deposit of chromium concentration followed by at depth of 0-30 cm for North bank auto-mechanic site. The lowest concentration level was at the Control site (90-120 cm depth). The result does not show if chromium concentration increases or decreases with respect to the depths. There is no defined pattern for the concentration of chromium in the soil. The findings are showing that the auto mechanic activities have little or no contribution to the concentration of the metal to the soil. According to CCME (2009) Chromium is one of those heavy metals with high environmental concentration which is steadily increasing due to industrial growth especially the development metal, chemical, and tanning industries. The ranges for this study were within the limits set for other countries. However the maximum values that were measured at Apir and North bank are above the limit of $22 \mathrm{mgkg}^{-1}$ set by Canada (CCME, 2009). But generally the values that were obtained when compared to that of other countries like Austria, Germany, France, Luxemborg, Sweden, and United States with value 100, 60, 150, $100-200,60$ and $400 \mathrm{mg} / \mathrm{kg}$ respectively are low. The findings of this study are is in accordance with that of Abida et al. (2009) who carried out a similar study in India and reported higher values of Cr concentration in 
refuse dumpsites soil. Yahaya et al. (2009) also reported similar concentration of Cr content in a similar study in Nigeria. The presence of $\mathrm{Cr}$ concentration in the study area soils may be attributed to the $\mathrm{Cr}$ content of oil waste on the sites that leaches into the underlying soil layer. The findings here obtained for agricultural soils are far below the maximum value of $750 \mathrm{mg} / \mathrm{kg}$ set by CCME (2009).

\section{Nickel (Ni) concentration in the soil}

From the results presented in Table 3, Ni concentration at the Apir location $(7.265 \pm 5.791 \mathrm{mg} / \mathrm{kg}$ ) was higher than that at North bank $(2.087 \pm 0.847 \mathrm{mg} / \mathrm{kg})$ while the Control site $(0.72 \pm 0.056 \mathrm{mg} / \mathrm{kg})$ showed trace concentration. The concentration of the Nickel increases down the depths. This enhanced level of $\mathrm{Ni}$ as compared to the control site could be attributed to the dumping of PVC plastics, nickel-cadmium batteries, motor oil and disposal sludge on the dumpsites (Jarup, 2003). The result of $\mathrm{Cd}$ and Ni concentrations recorded in this study disagrees with the earlier one obtained in a similar study by Pam et al. (2013) who reported higher concentrations of these heavy metals probably because the sampling areas focused on the refuse dumpsites. The results obtained for $\mathrm{Ni}$ concentration at Apir and North bank auto-mobile mechanic villages conform to that of Yahaya et al. (2009) that carried out a similar study in Nigeria.

Nickel has been considered to be an essential element for human and animal health . The permissible limit of nickel in plants recommended by WHO is $10 \mathrm{mg} / \mathrm{kg}$ (Ruqia et al., 2015). From Table 4 it was observed that there is no significant difference $(\mathrm{P}<0.05)$ in the concentration of Nickel across depth and across the three sites. Despite the high concentration of Nickel deposits at Apir and North bank auto mobile mechanic sites the concentration is far below the World Health Organization limit.

\section{Zinc $(\mathrm{Zn})$ concentration in the soil}

From Table 3 it was observed that the concentration of Zinc $(\mathrm{Zn})$ is highest at the depth of $0-30 \mathrm{~cm}$ and decreases down wards at the two auto-mobile mechanic sites while at the control the zinc concentration increases down the depths. The concentration of zinc is highest at the North bank site at $120.2 \mathrm{mg} / \mathrm{kg}$ within the depth of 0-30 cm followed by Apir at the depth of $0-30 \mathrm{~cm}$ on $35.5 \mathrm{mg} / \mathrm{kg}$ while UAM (control) had its highest level of $\mathrm{Zn}$ at the depth of $90-120 \mathrm{~cm}$ on $16.0 \mathrm{mg} / \mathrm{kg}$. No significant difference (Table 4) were observed across most of the depths for the three sites, however, significant differences were observed between Northbank (0-30 $\mathrm{cm})$, Apir (30-60, 60-90 and 90-120 cm) and UAM (0-30, 30-60 and 60-90 cm).

Zinc is one of the important trace element that plays a vital role in the physiological and metabolic process of many organisms. Nevertheless, higher concentration of Zinc can be toxic to the organism (Ruqia Nazir et al., 2015). Zinc also plays an important role in protein synthesis and is a metal which shows fairly low concentration in surface water due to its restricted mobility from place of rock weathering or from natural sources. WHO's recommended limit of zinc in plants is $50 \mathrm{mg} / \mathrm{kg}$ (Afzal Sha et al., 2011). The concentration of zinc at Apir auto-mechanic and UAM are below the tolerable limit for plants as presented by WHO. This shows that there more activities involving with zinc at North bank over the years and there is need for proper remediation, while at Apir though not yet above the allowable limit yet may need action before it gets to pose treats to plants and animals.

\section{Cobalt $(\mathrm{Co})$ concentration in the soil}

Results in Table 3 for Cobalt (Co) accumulation revealed trace concentration at the two auto-mobile mechanic villages however, there is no detectable concentration across the depths of the Control site. From Table 4, no significant differences were observed across the depths in the three sites. Significant differences were observed between Apir and Northbank, likewise Apir and UAM, but no significant difference was observed between Northbank and UAM (Table 4). The mean Co value in the study areas were close to the values o b t a i n e d b y Oguntimehin (2008) which show that the maximum levels of Co in the soils were below the detectable limit relative to established values of regulatory bodies or agencies. The Cobalt accumulation are not significant at these Automobile mechanic sites and it's environs meaning that it has no effect at the sites. Thus, a significant increase in soil Co content as a result of human activity has not occurred.

\section{Conclusion}

The following conclusions were drawn;

i. The soil samples were sandy clay loam in particle size distribution and slightly acidic in nature, with a moderate bulk density and porosity. The observed physico-chemical characteristics of the soil encourage heavy metals movements across the soil profiles.

ii. Elevated values of $\mathrm{Cu}, \mathrm{Mn}, \mathrm{Cr}, \mathrm{Ni}$, and $\mathrm{Zn}$ concentrations were observed in the soil at the Auto-mechanic villages when compared with the control samples and in some cases with the established guidelines of several countries. $\mathrm{Cu}, \mathrm{Mn}$, and $\mathrm{Zn}$ concentrations were highest at North bank but exist at other places with 
Cadmiun and Cobolt being the least and below the detectable point for it to be assumed to exist. $\mathrm{Cr}$, and $\mathrm{Ni}$ concentrations were higher at the Apir auto-mobile village.

iii. This raises environmental concern on the level of soil contamination by heavy metals, however, most Makurdi soils are not yet readily polluted to call for alarm but these contaminations can extend to nearby farmlands if measures to control the activities that increase the concentration at these sites are not implemented.

iv. Strict adherence to proper disposal at auto-mechanic wastes should be ensured.

v. Controlling runoff systems should be employed at auto-mechanic villages to reduce the impact of their waste on the nearest farmland.

vi. Further research be carried out on other heavy metals and in choice for a control or background value be a good distance away of the interested area of study.

vii. There is need further investigation within the immediate surroundings to check for Ni contamination of Apir Auto-mechanic village.

References

[1]. Abida B, Ramaiah M, Harikrishna, I.K and Veena, K (2009) Heavy Metal Pollution and Chemical Profile of Cauvery River water. E - Journal of Chemistry. 6(1): 47-52.

[2]. Akan J.C, Abdulrahaman F.I, Sodipo O.A and Lange, A.G (2010). Physicochemical parameters in soil and vegetable samples from Gongulon Agricultural site, Maiduguri, Borno state, Nigeria. J. Am. Sci., 6:12-16.

[3]. Alloway, B.J. (1996): Heavy metals in soils. Halsted press, John Wiley and Sons Inc London, United Kingdom.

[4]. Balasubramanian A, Boyle, A.R, and Voulvoulis, N (2007). Improving Petroleum Contaminated Land Remediation DecisionMaking through the MCA Weighting Process. Chemosphere 66:791-798.

[5]. Banjoko A, Sobulo RA (1994). Particle size distribution of Fe, Mn, Zn Cu and B in some Nigerian soils. Nig. J. Sci. 34:60-163.

[6]. Bouyoucos, G.J. (1962). Hydrometer Method improved for Making Particle

[7]. Size Analysis of Soils. Agronomy Journal 54:464-465.

[8]. Brady, N.C. (1990). The Nature and Properties of Soils. Macmillan Publishing Company, NY, NY. back to NJ Envirothon Soils Study Guide.

[9]. Brummer G, Herms U. (1982). Effects of accumulation of Air pollutants in Forest ecosystems, Reidel Publishing Company, pp. 233 -243 .

[10]. Canadian Council of Ministers of the Environment (CCME) (2009). Canadian Environmental Quality Guidelines. Ottawa, Ontario.

[11]. European Commission Director General Environment, ECDGE (2010). Heavy Metals and Organic Compounds from Wastes Used as Organic Fertilizers. Final Rep., July. WPA Consulting Engineers Inc. Ref. Nr. TEND/AML/2001/07/20, pp. 73-74. http://ec.europa.eu/environment/waste/compost/pdf/hm_finalreport.pd f

[12]. Jarup L (2003). Hazards of heavy metal contamination. Brit. Med. Bull., 68: 167-182.

[13]. Lenntech WT (2009). Chemical Properties, Health and Environmental Effects of Copper. Lenntech Water Treatment and Purification Holding B.V. www.lenntech.com/periodic/elements/cu.htm.

[14]. Luter L, Terngu A.J, Attah. S. (2001). Heavy metals in soils of auto- mechanic shops and refuse dumpsites in Makurdi Nigeria. Journal of Applied Science and Environmental Management, 5(1): 207-210.

[15]. Ministry for the Environment, (2011). Site Investigation and Analysis of Soils. Contaminated Land Management Guidelines No. 5, Ministry for the Environment, Wellington, New Zealand.

[16]. Myung, C.J. ( 2008). Heavy metal concentrations in soils and factors affecting metal uptake by plants in the vicinity of a Korean, CU-W Mine. Sensors 8: 2413-2423.

[17]. Oguntimehin I.I.K., (2008). Profile of heavy metals from automobile workshops in Akure, Nigeria. J. Eviron. Sci. Technol. 1(7):19 $-26$.

[18]. Ololade, I.A, Oloye, F.F and Adamu, H., Oluwole, O.D, Oluyede, O.P, Folasade, A and Ololade, O. (2015). Distribution and Potential Mobility Assessment of Some Hazardous Metals in Soil of Mechanic Workshops: A Case Study of Akoko Land in Nigeria International Research Journal of Pure \& Applied Chemistry 7(2): 54-68.

[19]. Pam, A. A., Sha'Ato, R and Offem, J.O. (2013). Evaluation of heavy metals in soils around auto mechanic workshop clusters in

[20]. Gboko and Makurdi, Central Nigeria. Journal of Environmental Chemistry and Ecotoxicology, 5(11): 298-306.

[21]. Ruqia,N.,Khan,M.,Masab,M. andShahean Z.(2015), Accumulation of heavy metals (Ni,Cu,Cd,Cr,Pb,Zn,Fe) in the soil ,water and plant and analysis of physio-chemical parameters of soil and water collected from Tanda Dam Kohat.

[22]. USEPA (1996) Report: recent development for our institu treatment of metal contaminated soil, U.S environment protection agency, office of solid waste and emergency response. Draft.

[23]. Usmanet, (2013). "Case report and analysis of vehicular population in Makurdi city and its suburbs",

[24]. Walkley, A. and I.A. Black (1934). An extermination of the Degtiarlf Method for

[25]. Determining Soil Organic Matter and Proposed Modification of the Chronic Acid Titration Method. Soil Sci. 37: 29-38.

[26]. Yahaya, M.I., Mohammed, S. and Abdullahi, B.K. (2009). Seasonal variation of heavy metals concentration in Abattoir dumping site soil in Nigeria. J. Appl. Sci. Environ. Manage. 13(4): 9-13.

[27]. Zhang, W.J. Jiang, F.B. and Qu, J.F. (2011). Global pesticide consumption and pollution: with China as a focus. Proceedings of the International Academy of Ecology and Environmental Sciences, 1(2): 125-144. 